Physical Disabilities: Education and Related Services, 2015, 34(2), 14-31. doi: 10.14434/pders.v34i2.19224

(C) Division for Physical, Health and Multiple Disabilities

PDERS

ISSN: 2372-451X

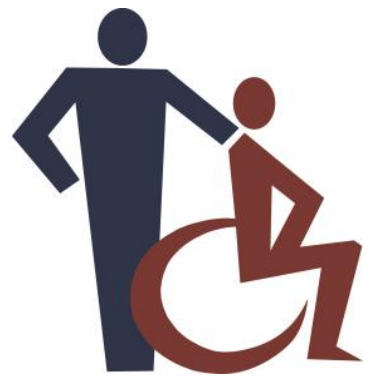

http://scholarworks.iu.edu/journals/index.php/pders/index

Article

\title{
COLLEGE STUDENTS WITH PHYSICAL DISABILITIES: COMMON ON CAMPUS, UNCOMMON IN THE LITERATURE
}

\author{
Nicholas W. Gelbar \\ University of Connecticut Health Center \\ Joseph W. Madaus \\ University of Connecticut
}

Allison Lombardi

University of Connecticut

Michael Faggella-Luby

Texas Christian University

Lyman Dukes

University of South Florida

\begin{abstract}
College students with physical disabilities were among the first students to receive disability supports in higher education in the United States, and the earliest journal articles in disability services focused almost exclusively on this cohort. As more students with a range of disability types have accessed higher education over the past 25 years, the body of professional literature has developed correspondingly. However, research related to students with physical disabilities is relatively sparse. The present study is a secondary analysis of a comprehensive systematic review of 1,036 journal articles published between 1951 and 2012, 615 of which were data based. Specifically, 81 of the 615 studies included at least one participant with a physical disability $(38.3 \%$ included a substantial number of individuals with physical disabilities) and were highlighted for analysis. The majority of studies used descriptive designs and only two studies were experimental. No studies investigated the effectiveness of specific programs or accommodations for students. Results indicated that more systematic, high quality research on the experiences of and services provided to college students with physical disabilities is necessary.
\end{abstract}

Keywords: young adult; physical impairments; systematic review 


\section{Introduction}

Modern service provision for college students with disabilities can largely trace its roots to programs that began as ad hoc supports for returning veterans with disabilities on college campuses, particularly those with physical or sensory difficulties (Gelber, 2005; Madaus, 2011; Scales, 1986) ${ }^{i}$. One of the earliest articles on college students with disabilities was written by Byron Atkinson in 1948 and published in a non-referred journal. Called "Students in Wheelchairs," the article began as follows:

An interesting and unusual educational program for handicapped students in the United States is currently being carried on at the University of California at Los Angeles. Here, eighteen veteran students in wheelchairs live, study, go to classes, and otherwise maintain a normal student existence. (p. 295)

In the next several years, other articles appeared in the literature specific to the handicapped student (Condon, 1951), the physically handicapped student (Condon, 1957; Condon \& Lerner, 1956), or physically disabled students (Berdie, 1955). These articles largely focused on veterans, but also discussed other postsecondary students with physical disabilities and provided descriptive examples of collaborations with state rehabilitation agencies, program descriptions, examples of accommodations provided to students, and even processes involved in providing services to students. Condon published what appeared to be the first two data-based research articles on the topic in 1957. In the first paper, Condon (1957a) presented the results of a national survey of 238 colleges and universities related to whether there was an "organized program" on campus, and if so, the number of students with different types of physical disabilities, as well as the available services. Completed surveys were received from 56 institutions and results indicated that the average number of students with disabilities was 15-25, and larger numbers of students with physical disabilities tended to be at larger institutions. It was also reported that although no institutions had a set policy regarding admissions, "practically all of the colleges required the approval of the college physician, the registrar, and the dean of students before the handicapped student was admitted" (p. 582). Services provided included ramps, elevator passes, recording devices, take-home exams, and preferential seating. In the second paper, Condon (1957b) presented the results of a survey sent to both current college students and students who had left college (i.e., graduates, drop outs, enrolled as graduate students). All participants had physical or sensory disabilities. Condon summarized that "the college trained physically handicapped student is competing quite well with the non-handicapped in the world of work" (p. 270), noting that with the exception of adults with cerebral palsy, the alumni were receiving salaries that were competitive with those received by workers without disabilities.

The impact of these postsecondary services, and advances in the field of special education (Jaques, 1962), lead to slow but steady access to college for individuals with disabilities. By 1962, Rusalem observed that "Physically disabled college students requiring one or more special education services are no longer a rarity on the American campus" (p. 161). However, despite this progress, Rusalem also noted that although more people with disabilities were ready for college, most institutions were not, as a whole, ready for them (cited in Jaques, 1962). 
It is important to bear in mind that these early postsecondary programs for students with disabilities pre-dated the access and accommodations mandated by Section 504 of the Rehabilitation Act of 1973 and the Americans with Disabilities Act of 1990. These programs were also often collaborations between colleges and state bureaus of rehabilitation (Atkinson, 1948; Berdie, 1955; Brooks \& Brooks, 1962; Condon, 1951 \& 1962; Rusalem, 1962) and often had both rehabilitation and training objectives (Chatterjee \& Mitra, 1998). These programs faced concerns similar to those expressed today, such as dealing with physical and instructional barriers, as well as attitudinal barriers, such as instructors' beliefs that accommodations and modifications "water down" the college curriculum (Jensen, McCrary, Krampe \& Cooper, 2004, Nugent, 1978; Skinner, 2007; Tuscher \& Fox, 1971). Literature on early programs emphasized the reality that students with physical disabilities were only seeking accommodations that resulted in college curricular access. As Atkinson (1948) stated, "The basic philosophy is that no special academic considerations, other than for admission, are made for [students with physical disabilities]" (p. 295).

Thus, in many ways, these groundbreaking postsecondary programs created the precedents of access in the form of accommodations that were codified in Section 504 (Bailey, 1979). Bailey elucidated that Section 504 was both "evolutionary and revolutionary" (p. 81). It was evolutionary in that it systemized the policies of existing programs and revolutionary because the law mandated those policies be implemented on any campus that received federal funding. At its core, Section 504 required that reasonable and appropriate accommodations be provided to individuals with disabilities to allow access to the college curriculum and physical plant (34 C.F.R. Part 104.4).

The impact of Section 504 and later, the ADA, on student access to higher education cannot be understated, as these mandates led to the "scaling up" of disability services on college campuses across the United States for all students with disabilities, including those with physical disabilities. Ultimately, this led to the evolution and eventual professionalization of student disability services programs (Madaus, 2011).

While the initial focus of disability services and the corresponding professional literature was on students with physical disabilities, student demographics have since changed. Students with disabilities make up $11 \%$ of all undergraduates (U.S. Department of Education, 2015), with services provided to individuals with a range of disabilities, most often mental illness/depression (31\%) and attention deficit disorder (22\%; U.S. Department of Education, 2014). Consequently, research on postsecondary disability services focuses largely on "invisible" disabilities (Madaus, Gelbar, Dukes, Lalor, Lombardi, Kowitt, \& Faggella-Luby, submitted); however, colleges continue to admit and serve individuals with physical disabilities with these students currently constituting $9.3 \%$ of college students with disabilities or approximately $1 \%$ of the total population of college students (U.S. Department of Education, 2014). Given that published professional literature guides policy, professional development, and to what extent a topic is acted on or ignored, it is important to understand the current and evolving status of the professional literature specific to students with physical disabilities (McFarland, Williams, \& Miciak, 2013; Peña, 2014; Plotner, Shogren, \& Strauser, 2011). The present study examined 615 data-based manuscripts related to postsecondary education and disability to determine how many included at least one participant with a physical disability. In addition, the number of such 
articles published was examined over time periods, as was the broad area under investigation, key findings, the sample sizes explored, and the methodologies employed.

\section{Methods}

In order to complete the current study, the authors conducted a secondary analysis of data culled from a systematic review of the literature on college students with disabilities (Madaus, Lalor, Gelbar, \& Kowitt, 2014; Faggella-Luby, Lombardi, Lalor, \& Dukes, 2014). A complete description of the methods used in the comprehensive examination is provided in Madaus and colleagues (2014), and will also be briefly explained here. The following Boolean codes were entered into ERIC, Academic Search Premier, PsycInfo, and Medline: (university student or college student or postsecondary education) AND (disability or visual impairment or hearing impairment or deaf or ADHD or dyslexia or blind or handicapped or mental illness or mobility impairment). The search, spanning the years 1955-2012, yielded 9,131 entries. An additional hand search of peer reviewed articles was also included and expanded the date range to 1951.

The title and abstract of every article was examined yielding 1,036 that met screening criteria. Inclusion criteria were as follows: First, the study had to be about postsecondary education for students with disabilities (including students, faculty, disability services, and college personnel). Second, articles specific to students focused on those who were accepted to, matriculated in, withdrawn from, or graduated from a postsecondary institution. Articles about secondary school students in transition and secondary transition programs were excluded. Finally, articles had to be published in peer-reviewed journals.

The articles that met the inclusion criteria were sorted into a set of topical domains and subdomains to organize their analysis (see Madaus et al., 2014 for a description of the process used to create and validate the domain structure). The four domains were (a) student-level studies, (b) program or institution-level studies, (c) faculty/non disability support staff-level studies, and (d) construct development-focused studies. Table 1 contains definitions of each domain. The four domains make up a taxonomy of the literature on postsecondary education and disability.

Table 1

Definitions of Domains and Subdomains

\begin{tabular}{ll}
\hline \multicolumn{1}{c}{ Domain } & \multicolumn{1}{c}{ Domain Description } \\
\hline Student-level studies & $\begin{array}{l}\text { Articles describe experiences and/or perceptions of students with } \\
\text { disabilities in and after higher education. }\end{array}$ \\
\hline $\begin{array}{l}\text { Program or } \\
\text { institution-level } \\
\text { studies }\end{array}$ & $\begin{array}{l}\text { Articles describe service provision by the disability services office in a } \\
\text { higher education institution. They can also relate to institutional policies } \\
\text { and procedures pertaining to students with disabilities. }\end{array}$ \\
$\begin{array}{l}\text { Faculty/ } \\
\text { non-disability support } \\
\text { staff-level studies }\end{array}$ & $\begin{array}{l}\text { Articles describe knowledge, attitudes, and beliefs of faculty and non- } \\
\text { disability services personnel to enhance access to higher education for } \\
\text { students with disabilities. They can also relate to education or support for }\end{array}$ \\
\hline
\end{tabular}


faculty and staff in this practice.

Construct Development-level studies
Articles describe development, evaluation, or validation of a variable that includes development/validation of assessment instruments, evaluation metrics, theoretical models of service delivery, standards of practice, or ethics. The variable must be under proposal, in development, or being used in practice to gather empirical evidence.

The articles in the comprehensive analysis were divided into two broad categories based on whether or not an article presented original data. This was defined as articles presenting data through the use of surveys, measurement or evaluation tools, observations, or interviews. Program descriptions and literature reviews were not considered to be original data. Of the 1,036 articles that met the inclusion criteria, 615 presented original data $(59.3 \%)$. Several study characteristics were coded, including the research methodology employed, location (U.S. or international), and setting (2-year or 4-year institution). Additionally, sample characteristics were documented including race/ethnicity, disability category, gender, and class standing (when the number of individuals in the sample meeting these criteria was present in a table or the text ${ }^{\mathrm{ii}}$ ). For the current inquiry, the data base was further filtered to include only those articles that featured at least one student with a physical disability. Thus, articles about programs that served students with disabilities, including those with physical disabilities, were not included in this analysis.

\section{Results}

\section{Number of Articles}

Eighty one of the $615(13.2 \%)$ articles with at least one participant with a physical disability were selected. As depicted in Figure 1, approximately 50\% of the studies $(n=40)$ were published between 2007 and 2012 and 84\% $(n=68)$ were published since 1995 emphasizing the recency of this research base, which represent $6.5 \%$ and $11.1 \%$ of the original sample respectively. Table 2 contains a summary of the number of articles including students with physical disabilities across each domain and subdomain.

\section{Area of Research}

The majority of the articles meeting criteria for this review (86\%) were published in the StudentLevel Studies domain. Fifty-five (68\%) were about the experiences of students with disabilities in college, 19 articles $(23.5 \%)$ included profiles of students with disabilities, and an additional 18 $(22.2 \%)$ were related to access issues. 


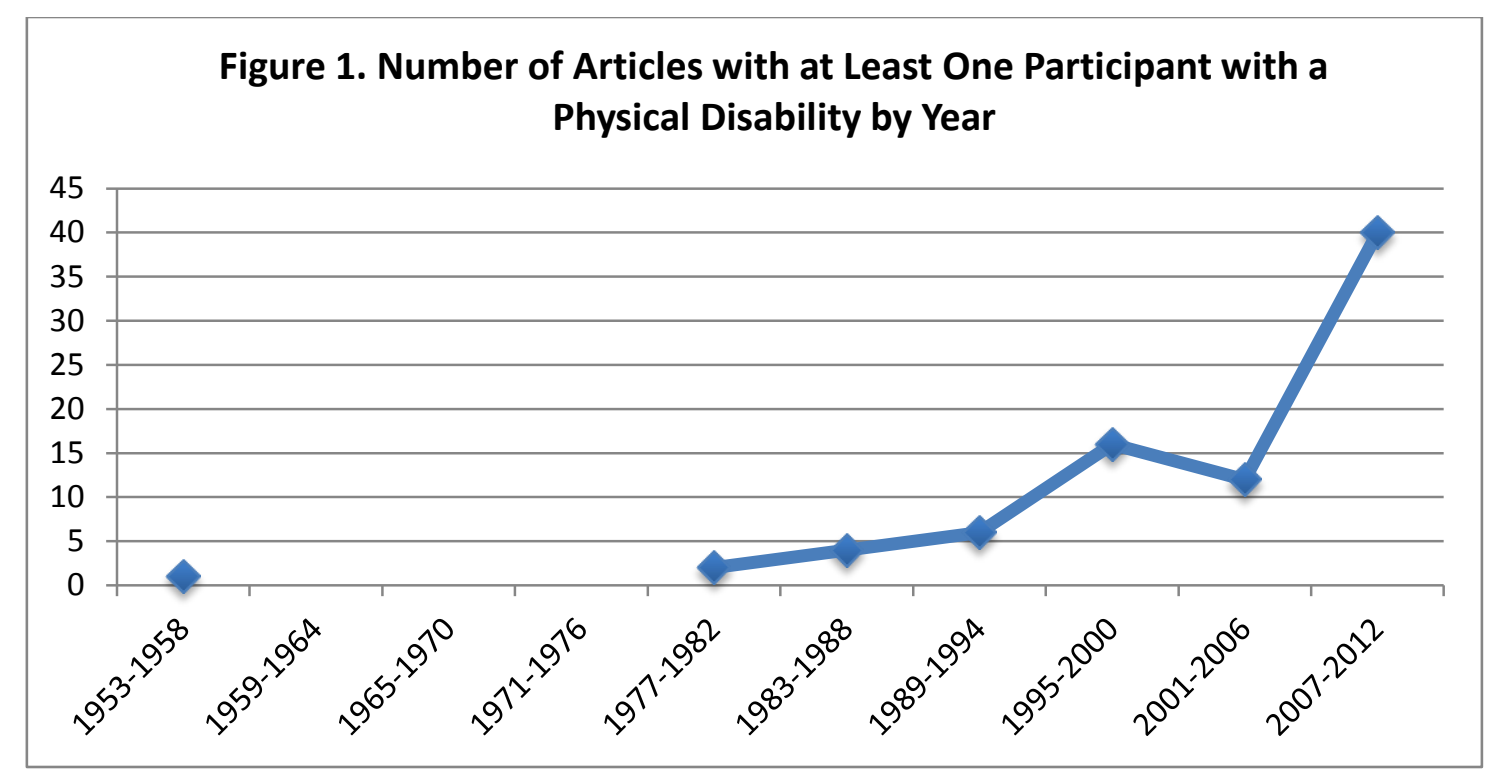

Table 2

Number of Articles on Physical Disability Only by Domain and Subdomain

\begin{tabular}{lc}
\hline Domain/Subdomain & $n$ \\
\hline Student-Level & 70 \\
Experience & 55 \\
Profile/Stats & 19 \\
Access & 18 \\
Learning/Study Skills & 1 \\
Self Determination & 7 \\
Technology & 7 \\
Career & 4 \\
Disability Services & 4 \\
Description of Disability Programs & 3 \\
Policies/Procedures & 2 \\
Programs for Specific Cohorts & 2 \\
Faculty-Level & 1 \\
Faculty Knowledge & 1 \\
Conceptual Level & 1 \\
Conceptual Models & 6 \\
Assessment/ & 1 \\
Instrument Development & \\
\hline
\end{tabular}

Note. Articles could be coded into multiple subdomains. 


\section{Sample Sizes}

As depicted in Table 3, the sample size of persons with physical disabilities in many of the studies represented only a small percentage of the overall study population. For example, only 10 studies included sample sizes of individuals with physical disabilities greater than 100 . Five studies described sample sizes of persons with physical disabilities between 51 and 99, while 27 had samples sizes between 11 and 50. Thirty-nine studies (49\%) had sample sizes of less than 10 . Only 21 studies $(26 \%)$ were predominantly composed of college students with physical disabilities (see the bolded diagonal cells in Table 3) and 10 studies included samples of greater than 100 individuals with physical disabilities (see the italicized cell in Table 3).

Table 3

Total Sample Size versus Sample Size with Physical Disability

\begin{tabular}{lcccc}
\hline Total Sample Size & \multicolumn{4}{c}{ Sample Size with Physical Disability } \\
\cline { 2 - 5 } & $1-10$ & $11-50$ & $51-99$ & $100+$ \\
\hline $1-10$ & $\mathbf{1 2}$ & 0 & 0 & 0 \\
$11-50$ & 18 & $\mathbf{8}$ & 0 & 0 \\
$51-99$ & 3 & 11 & $\mathbf{1}$ & 0 \\
$100+$ & 6 & 8 & 4 & 10 \\
\hline
\end{tabular}

\section{Research Methods Used}

Research methods were also documented and the proportion of the sample with physical disabilities varied by methodology. For example, eleven of the studies (13.6\%) utilized mixed methods, but only one of these included a comparison group. This study compared the performance of students with and without disabilities on the Learning for All Questionnaire (Avramidis \& Skidmore, 2004) and included only three participants with physical disabilities resulting in a sample size too small to allow for meaningful between group comparisons. Six studies employed interviews/focus groups and surveys. Three included open-ended questionnaires and surveys and two described case studies and surveys. The data from the mixed methods studies were included in the other research methodology categories to enable relative comparisons of their use across the entire sample.

The most commonly employed methodology was the descriptive-quantitative approach ( $n=38$; 47\%; see Table 4). Eleven of the study samples were comprised primarily of individuals with physical disabilities. Most were simple descriptive studies using surveys or focus groups $(n=26$; $32.1 \%$ ) and eight of the survey studies primarily contained individuals with physical disabilities. Eighteen of the 81 studies compared two or more groups $(22.2 \%)$ with two including large samples of individuals with physical disabilities. Fourteen (17.2\%) were correlational studies and four of these were composed primarily of individuals with physical disabilities. Qualitative methodology was the next most common technique employed $(n=30 ; 37 \%)$ with 16 of the 30 studies focusing primarily on individuals with physical disabilities. Only two of the 81 studies 
(2.5\%) used group designs to test interventions and only one study met the criteria to be considered a randomized control trial.

\section{Summary of Key Findings}

Table 4 provides a summary of the research methodology used in the studies summarized here. One of the eight survey studies reported the experiences of university students with disabilities using augmentative and alternative communication (Atanasoff, McNaughton, Wolfe, \& Light, 1998 ) and found that e-mail communication was more effective than face-to-face or other written forms of communication. Fichten and colleagues $(2000 ; 2001)$ reported on the accessibility of computers for postsecondary students with disabilities in two articles; the studies included focus groups $(n=12)$, interviews $(n=37)$, and surveys $(n=725)$. Twenty-three of the interviewed students and 358 of the surveyed students reported a physical disability. A high proportion (41\%) of students indicated they needed adaptions to access computers. A similar study surveyed the need for information technology training among 324 college students with disabilities in South Korea (Kim, Son, \& Vance, 2012) and, of those, 52\% reported having a physical disability. These college students with disabilities indicated a need for further training in the area of information technology.

Table 4

Number of Articles by Research Methodology

\begin{tabular}{lcc}
\hline & \multicolumn{2}{c}{ Number of Articles } \\
\cline { 2 - 3 } \multicolumn{1}{c}{ Research Methodology } & Total & $\begin{array}{c}\text { Primarily Physical } \\
\text { Disability }\end{array}$ \\
\hline Descriptive-Quantitative & & 11 \\
Simple Descriptive & 38 & 8 \\
Comparative & 27 & 2 \\
Correlation & 18 & 4 \\
Group Design & 14 & 1 \\
Mixed methods & 2 & 3 \\
Qualitative & 11 & 16 \\
Phenomenological designs & 30 & 10 \\
Case Study & 29 & 6 \\
Grounded Theory & 9 & 4 \\
\hline
\end{tabular}

Mamiseishvilli and Koch (2011) analyzed data from the Beginning Postsecondary Students Longitudinal Study to understand the characteristics that influenced persistence from first to second year for the 1,910 individuals who began college in Fall 2003, of which a plurality $(n=$ 400, 20.9\%) reported having a physical impairment. Individuals with physical disabilities were less likely to persist than students in other disability categories. Two hundred and eighty of the 400 persisted; which was a statistically significant proportion (70\%) when compared to the other participating disability categories $(76.4 \%$ persisted). A similar study investigated the quality of life of 203 college students with disabilities in the Cote D'Ivoire (Nandjui et al., 2008). Most of 
the sample (89.2\%) reported having a physical disability. The participants reported that building accessibility was a major barrier, but that the instructional staff at their college was very accessible. In another survey of international college students with physical disabilities $(n=12)$, physical access was again identified the largest barrier (O’Connor \& Robinson, 1999) and it also determined that students did not perceive disability services staff as having adequate knowledge of the experiences of people with disabilities.

Sanders and Dubois (1996) conducted a survey of 29 university students with disabilities of whom 17 had physical disabilities; with 12 participants using wheelchairs. These 12 reported a need for greater campus resources and having more negative daily events as compared to students who did not use wheelchairs.

Of the 18 studies that compared one or more groups, one study investigated the relationship between gender and disability category on GRE performance (Bennett, Rock, \& Jirele, 1989). Five hundred individuals without disabilities were compared to 105 individuals with physical disabilities and 337 individuals with visual impairments. Gender was a statistically significant predictor of Verbal and Quantitative scores (but not for Analytical scores) for the population with physical disabilities as compared to those with no disability. Males outperformed females on both scales. The second study, conducted in the UK, investigated the relationship between degree classes (the UK degree ranking system) and disability status for 270,180 students who received degrees in the 2004-2005 school year (Richardson, 2009). Of these, 480 individuals with physical disabilities received degrees and $58.9 \%$ of them were high value degrees (Level I and II(i)), indicating superior academic performance. This was comparable to the percentage of individuals without disabilities (62.4\%) and the odds ratio for the comparison was not statistically significant.

In one of the 14 correlational studies, data from the 2008 American College Health AssociationNational College Health Assessment II was analyzed to determine the sexual and substance-use behavior of college students with disabilities. Individuals with physical disabilities made up $0.7 \%(\mathrm{n}=426)$ of the sample (Bernert, Ding, \& Hoban, 2012). Overall, college students with disabilities were more likely to engage in these behaviors as compared to students without disabilities. The data were not analyzed by disability category, so it is not possible to examine the behavioral prevalence for students with physical impairments.

In another correlation study, a secondary analysis of Career Workforce Skills Training programs at community colleges was conducted (Flannery et al., 2011). Approximately 50\% of 465 students participating had a physical impairment $(n=199)$. Ultimately, $44 \%$ of the individuals with physical disabilities dropped out of these programs $(n=88)$. The average annual income for individuals of all disability types completing the program was more than double the noncompleters $(\$ 20,178$ vs. $\$ 8,484)$.

In the third of the four correlational studies, students with disabilities who transferred from twoto four-year colleges were examined (Ponticelli \& Russ-Eft, 2009) with the data being gathered over a period of 12 years. The sample included 31,590 students with disabilities of whom 10,769 had a physical disability. Of these, 5,395 were described as having a mobility impairment, and 5,373 were defined as having some other physical disability. Persons with a mobility diagnosis 
were $67 \%$ less likely to transfer to a 4 -year institution, which was statistically significant. Having another physical impairment, however, was not a statistically significant predictor of four-year college transfer.

The remaining correlational study being highlighted was a measurement validation of the Rosenberg Self-Esteem (RSE) scale. The RSE was administered to 68 college students who played wheelchair basketball (Vermillion \& Dodder, 2007). It was determined the instrument demonstrates acceptable reliability for this population (Cronbach's alpha $=0.86$ ) and the onefactor structure RSE was confirmed using confirmatory factor analysis. It should be noted that this is the only study to use college students with orthopedic disability as a norming sampling to demonstrate the validity of an instrument.

Of the 30 qualitative studies, most $(n=29 ; 35.8 \%)$ utilized a phenomenological design, while nine used the case study method $(11.1 \%)$, and four employed a grounded theory approach $(0.5 \%)$. The vast majority of these articles generally addressed the experiences of college students with physical disabilities ( $n=13$; Bessant, 2012; Cortes, Hollis, Amick, \& Katz, 2002; Nelson, et al., 1993; Papasotiriou \& Windle, 2012; Poussu-Olli, 1999; Roessler \& Kirk, 1998), with seven articles specifically discussing access issues (Gibson \& Kendall, 2010; Gilson \& Dymond, 2012; Israelite, Swartz, Huynh, \& Tocco, 2005; Moswela \& Mukhopadhyay, 2011; Opini, 2012; Parker, 1999; Wessel, Wentz, \& Markle, 2011). Additionally, one article addressed self-determination (Parker, 1999), while three discussed the transition from college to career (Israelite, Swartz, Huynh, \& Tocco, 2005; Roessler et al., 2009, Roessler \& Kirk, 1998). Two studies described disability programs for individuals with physical disabilities and included descriptions of program/university policies (Hadjikakou \& Hartas, 2008; Lechtenberger, Barnard-Brak, Sokolosky, \& McCrary, 2012).

As noted, only two of the 81 studies (2.5\%) used group designs to test interventions and only one study met the criteria to be considered a randomized control trial. One explored the use of a computer-based educational center on students' academic achievement (Shell, Horn, \& Severs, 1988) while the other was a randomized control trial investigating the effect of self-advocacy and conflict resolution training on students' requests for accommodations (Palmer \& Roessler, 2000). The sample in the latter study was composed primarily of individuals with physical disabilities. These studies and one study that used a mixed methods approach (Avramidis \& Skidmore, 2004) were the only studies to employ any control or comparison group.

\section{Location of the Studies}

The location and setting of the studies were also examined, however studies often involved multiple locations or settings so the results add to more than 81. A majority of the studies were conducted in the United States $(n=42 ; 51.9 \%), 15$ studies were conducted in Great Britain (18.5\%), 10 in Canada (11.1\%), and 14 (17.3\%) in other international locations. Forty (49.4\%) were conducted at four-year colleges and universities with 38 carried out at international institutions (47\%). Eleven were completed at 2-year colleges (13.6\%). 


\section{Disabilities Studied}

Table 5 contains a summary of the other disability categories represented in the studies and summarized by frequency, with the most common being visual impairment $(n=50)$, hearing impairment $(n=48)$, learning disability $(n=37)$, and psychiatric disability $(n=34)$. A majority of these included demographic information on the gender of the sample $(n=53)$, while 19 provided information on race/ethnicity or class standing.

Table 5

Number of Articles by Sample Demographics

\begin{tabular}{lc}
\hline Demographic & $n$ \\
\hline Disability & 51 \\
Visual Impairment & 49 \\
Hearing Impairment & 47 \\
Learning Disability & 34 \\
Psychiatric & 32 \\
Other & 24 \\
Multiple & 24 \\
Other Health Impairment & 16 \\
Students without disabilities & 14 \\
Speech/Language & 7 \\
Autism & 7 \\
Acquired Brain Injury & 2 \\
Developmental & 1 \\
Intellectual Disability & 9 \\
Not clear & 19 \\
Race/ethnicity & 53 \\
Gender & 19 \\
Class standing & \\
\hline
\end{tabular}

\section{Discussion}

It is important to examine the experiences of students with physical disabilities in higher education as they have unique strengths and challenges in relation to others; yet the present results indicate that research on college students with this type of disability is both sparse and fragmented. Moreover, given the broad range of study topics, methods used, findings and results across the existing literature on the population, it appears that results regarding college students with physical disabilities can be best described as idiosyncratic. Most of the summarized research focused on the experiences of students with physical disabilities in the college environment.

Another significant finding of this analysis was that no studies investigated the effectiveness of specific practices or accommodations for these students and there is a paucity of experimental or 
quasi-experimental research to measure the effectiveness of given practices. In fact, only a few studies provided examples of specific instructional or access approaches designed for college students with physical disabilities and none of these provided evidence of their efficacy or success. Further research should provide a more holistic understanding of the experiences of college students with physical disabilities and the programs that serve them.

The studies included in this analysis describe the who is or what is of college students with physical disabilities. Given the idiosyncratic nature of the current literature base and research findings, many questions remain to be answered. What works well with regard to college-level supports and services for this group? Additionally, more focus on research studies that could be categorized within the three remaining domains (program or institution-level studies, faculty/non-disability support staff-level studies, and construct development-focused studies) are important to prioritize. Such research studies will allow the field to address the what works question with regard to effective programs and support for students with physical disabilities.

\section{Summary}

While students with physical disabilities were a major impetus for the birth of the postsecondary disability services field, the current examination of the literature base highlights a dearth of studies related to this cohort, few that provide evaluative data related to practices, and fewer still that are experimental or quasi-experimental. Furthermore, the current research base is fragmented and does not focus solely on the experiences of college students with physical disabilities, as they were often included with heterogeneous samples of college students with disabilities. Fortunately, the current trend over the past five years suggests that more studies are now focusing on the population. Potentially, the results offer suggestions to researchers who have interest in addressing students with physical disabilities, and in so doing, may offer the discipline with data-based recommendations intended to improve services. 


\section{References}

Atanasoff, L. M., McNaughton, D., Wolfe, P. S., \& Light, J. (1998). Communication demands of university settings for students using augmentative and alternative communication (AAC). Journal of Postsecondary Education and Disability, 13(3), 32-47.

Atkinson, B. H. (1948). Students in wheelchairs. The Phi Delta Kappan, 29(7), 295-297.

Avramidis, E., \& Skidmore, D. (2004). Reappraising learning support in higher education. Research in Post-Compulsory Education, 9(1), 63-82. http://dx.doi.org/10.1080/13596740400200167

Bailey, C. W. (1979). Adapting to the revolution of equal opportunity for the handicapped. New Directions for Higher Education, 25, 81-111. http://dx.doi.org/10.1002/he.36919792510

Bennett, R. E., Rock, D. A., \& Jirele, T. (1989). Sex group membership as a confounding factor in handicapped students' GRE General Test performance. Journal of Postsecondary Education and Disability, 7(2), 61-68.

Berdie, R. F. (1955). Counseling for physically disabled students. The Journal of Higher Education, 26(9), 475-478. http://dx.doi.org/10.2307/1977938

Bernert, D. J., Ding, K., \& Hoban, M. T. (2012). Sexual and substance use behaviors of college students with disabilities. American Journal of Health Behavior, 36(4) 459-471.

Brooks, S. T., \& Brooks, B. H. (1962). Handicapped Students and the California Two-Year College. The Junior College Journal, 33(1), 50-56.

Chatterjee, L., \& Mitra, M. (1998). Evolution of federal and state policies for persons with disability in the United States: Efficiency and welfare impacts. The Annals of Regional Science, 32(3), 347-365. http://dx.doi.org/10.1007/s001680050078

Condon, M. E. (1951). This college concentrates on helping the handicapped student. Journal of Rehabilitation, 17(3), 14-16.

Condon, M. E. (1957a). A survey of special facilities for the physically handicapped in the colleges. Personnel and Guidance Journal, 35(9), 579-583. http://dx.doi.org/10.1002/j.2164-4918.1957.tb01975.x

Condon, M. E. (1957b). 10-year survey of physically handicapped students at the City College of New York. Personnel and Guidance Journal, 36(4), 268-271. http://dx.doi.org/10.1002/j.2164-4918.1957.tb01039.x

Condon, M. E. (1962). The facilitation of the education of the physically disabled college student. Rehabilitation Literature, 23(9), 266-274. 
Condon, M. E., \& Lerner, R. S. (1956). Program adjustments for the physically handicapped at the college level. Personnel and Guidance Journal, 35(1), 41-42. http://dx.doi.org/10.1002/j.2164-4918.1956.tb01699.x

Cortés, M. C., Hollis, C., Amick, B., \& Katz, J. N. (2002). An invisible disability: Qualitative research on upper extremity disorders in a university community. Work: Journal of Prevention, Assessment \& Rehabilitation, 18(3), 315-321.

Faggella-Luby, M., Lombardi, A., Lalor, A., \& Dukes III, L. L. (2014). Methodological trends in disability and higher education research: Historical analysis of the Journal of Postsecondary Education and Disability. Journal of Postsecondary Education and Disability, 27(4), 357-368.

Fichten, C. S., Asuncion, J. V., Barile, M., Fossey, M., \& Simone, C. D. (2000). Access to educational and instructional computer technologies for post-secondary students with disabilities: Lessons from three empirical studies. Journal of Educational Media, 25(3), 179-201.

Fichten, C. S., Asuncion, J. V., Barile, M., Généreux, C., Fossey, M., Judd, D., \& ... Wells, D. (2001). Technology integration for students with disabilities: Empirically based recommendations for faculty. Educational Research and Evaluation, 7(2-3), 185-221. http://dx.doi.org/10.1076/edre.7.2.185.3869

Flannery, K. B., Benz, M. R., Yovanoff, P., kato, M. M., \& Lindstrom, L. (2011). Predicting employment outcomes for consumers in community college short-term programs. Rehabilitation Counseling Bulletin, 54(2), 106-117.

Gelber, S. (2005). A "Hard Boiled Order": The reeducation of disabled WWI veterans in New York City. Journal of Social History, 39(1), 161-180. http://dx.doi.org/10.1353/jsh.2005.0101

Gibson, S., \& Kendall, L. (2010). Stories from school: Dyslexia and learners' voices on factors impacting on achievement. Support for Learning, 25(4), 187-193.

Gilson, C. L., \& Dymond, S. K. (2012). Barriers impacting students with disabilities at a Hong Kong university. Journal of Postsecondary Education and Disability, 25(2), 103-118.

Hadjikakou, K., \& Hartas, D. (2008). Higher education provision for students with disabilities in Cyprus. Higher Education, 55, 103-119.

Israelite, N., Swartz, K., Huynh, J., \& Tocco, A. (2005). Post-Secondary students and graduates with disabilities: The transition from university to work. Exceptionality Education Canada, 15(2), 5-26.

Jaques, M. E. (1962). Review of the month [Review of the book Guiding the Physically Handicapped College Student, by H. Rusalem]. Rehabilitation Literature, 23(9), 275-277. 
Jensen, J. M., McCrary, N., Krampe, K., \& Cooper, J. (2004). Trying to do the right thing: Faculty attitudes toward accommodating students with learning disabilities. Journal of Postsecondary Education and Disability, 17(2), 81-90.

Kena, G., Musu-Gillette, L., Robinson, J., Wang, X., Rathbun, A., Zhang, J., . . Dunlop Velez, E. (2015). The Condition of Education 2015 (NCES 2015-144). U.S. Department of Education, National Center for Education Statistics. Washington, DC. Retrieved from http://nces.ed.gov/pubs2015/2015144.pdf.

Kim, D., Son, J., \& Vance, M. L. (2012). Preparing for the future IT era: Perceptions of students with disabilities about IT training in South Korea. Journal of Postsecondary Education and Disability, 25(4), 297-308.

Lechtenberger, D., Barnard-Brak, L., Sokolosky, S., \& McCrary, D. (2012). Using wraparound to support students with developmental disabilities in higher education. College Student Journal, 46(4), 856-866.

Madaus, J. W. (2011). The history of disability services in higher education. New Directions for Higher Education, 2011(154), 5-15. http://dx.doi.org/10.1002/he.429

Madaus, J. W., Gelbar, N. W., Dukes, L., Lalor, A., Lombardi, A., Kowitt, J., \& Faggella-Luby, M. (submitted). Professional literature on students with disabilities in postsecondary education: The road traveled and the road ahead. Journal of Diversity in Higher Education.

Madaus, J. W., Lalor, A. R., Gelbar, N. W., \& Kowitt, J. (2014). The Journal of Postsecondary Education and Disability: From past to present. Journal of Postsecondary Education and Disability, 27, 347-356.

Madaus, J. W., \& Vance, M. L. (2009). Veterans with disabilities in postsecondary education. Journal of Postsecondary Education and Disability, 22(1), 10-17.

Mahan, G. H. (1974). Special provisions for handicapped students in colleges. Exceptional Children, 41(1), 51-53.

Mamiseishvili, \& K., Koch, L. C. (2010). First-to second-year persistence of students with disabilities in postsecondary institutions in the United States. Rehabilitation Counseling Bulletin, 54(2), 93-105.

McFarland, L., Williams, J., \& Miciak, J. (2013). Ten years of research: A systematic review of three referred LD journals. Learning Disabilities Research and Practice, 28(2), 60-69. http://dx.doi.org/10.1111/1drp.12007

Moswela, E., \& Mukhopadhyay, S. (2011). Asking for too much? The voices of students with disabilities in Botswana. Disability \& Society, 26(3), 307-319. http://dx.doi.org/10.1080/09687599.2011.560414 
Nandjui, B. M., Alloh, D. A., Manou, B. K., Bombo, J., Twoolys, A., \& Pillah, A. (2008). Quality of life assessment of handicapped students integrated into the ordinary higher education system. Annales de Readaptation et de Medecine Physique, 51(2), 109-113.

Nelson, J., Smith, D. J., Appleton, V., \& Raver, K. (1993). Achievement-related beliefs of college students with disabilities. Journal of Postsecondary Education and Disability, 10(2), 9-20.

Nugent, T. J. (1978). More than ramps and braille. American Education, 14(7), 11-18.

O'Connor, U., \& Robinson, A. (1999). Accession or exclusion? University and the disabled student: A case study of policy and practice. Higher Education Quarterly, 53(1), 88-103.

Opini, B. (2012). Barriers to participation of women students with disabilities in university education in Kenya. Journal of Postsecondary Education and Disability, 25(1), 78-99.

Palmer, C., \& Roessler, R. T. (2000). Requesting classroom accommodations: Self-Advocacy and conflict resolution training for college students with disabilities. Journal of Rehabilitation, 66(3), 38-43.

Papasotiriou, M., \& Windle, J. (2012). The social experience of physically disabled Australian university students. Disability \& Society, 27(7), 935-947.

Parker, V. (1999). Personal assistance for students with disabilities in HE: The experience of the University of East London. Disability \& Society, 14(4), 483-504.

Peña, E. V. (2014). Marginalization of published scholarship on students with disabilities in higher education journals. Journal of College Student Development, 55(1), 30-40. http://dx.doi.org/10.1353/csd.2014.0006

Plotner, A. J., Shogren, K. A., \& Strauser, D. (2011). Analyzing the emphasis on transition in rehabilitation counseling journals: A content analysis. Journal of Applied Rehabilitation Counseling, 42, 27-32.

Ponticelli, J. E., \& Russ-Eft, D. (2009). Community college students with disabilities and transfer to a four-year college. Exceptionality, 17(3), 164-176. http://dx.doi.org/10.1080/09362830903028473

Poussu-Olli, H. (1999). To be a disabled university student in Finland. Disability \& Society, 14(1), 103-113.

Richardson, J. T. E. (2009). The academic attainment of students with disabilities in UK higher education. Studies in Higher Education, 34(2), 123-137. 
Roessler, R. T., \& Kirk, H. M. (1998). Improving technology training services in postsecondary education: Perspectives of recent college graduates with disabilities. Journal of Postsecondary Education and Disability, 13(3), 48-59.

Roessler, R. T., Hennessey, M. L., Hogan, E. M., \& Savickas, S. (2009). Career assessment and planning strategies for postsecondary students with disabilities. Journal of Postsecondary Education and Disability, 21(3), 126-137.

Ryan, D. (1993). The federal government and higher education for students with disabilities. (ERS\#ED367-079): ERIC Clearinghouse on Disabilities and Gifted Education.

Rusalem, H. (1962). The physically handicapped student and the college faculty. College and University, 32(2), 161-167.

Sanders, K. S., \& DuBois, D. L. (1996). Individual and socio-environmental predictors of adjustment to college among students with disabilities. Journal of Postsecondary Education and Disability, 12(2), 28-43.

Scales, W. (1986). Postsecondary education for disabled students—written testimony. AHSSPPE Bulletin, 4(1), 21-32.

Section 504 of the Rehabilitation Act of 1973 Regulations, 34 C.F.R. $\S 104.1$.

Shell, D. F., Horn, C. A., \& Severs, M. K. (1988). Effects of a computer-based educational center on disabled students' academic performance. Journal of College Student Development, 29(5), 432-440.

Skinner, M. E. (2007). Faculty willingness to provide accommodations and course alternatives to postsecondary students with learning disabilities. International Journal of Special Education, 22(2), 32-45.

Tuscher, J. \& Fox, G. C. (1971). Does the open door include the physically handicapped? Journal of Rehabilitation, 37(5), 10-13.

United States Department of Education, National Center for Education Statistics (2015). Digest of Education Statistics, 2013 (2015-011). Retrieved from https://nces.ed.gov/fasstfacts/display.asp?id=60

United States Department of Education, National Center for Education Statistics (2014, October). Profile of undergraduate students: 2011-12: Web Tables. Retrieved from http://nces.ed.gov/pubsearch/pubsinfo.asp?pubid $=2015167$

Vermillion, M., \& Dodder, R. A. (2007). An examination of the Rosenberg Self-Esteem Scale using collegiate wheelchair basketball student athletes. Perceptual and Motor Skills, 104(2), 416-418. 
Wessel, R. D., Wentz, J., \& Markle, L. L. (2011). Power soccer: Experiences of students using power wheelchairs in a collegiate athletic club. Journal of Postsecondary Education and Disability, 24(2), 155-172.

${ }^{\mathrm{i}}$ The first college program for individuals with disabilities was Gallaudet University, but this involved the creation of a separate college versus offering services on an existing campus (Madaus, 2011).

ii The reviewers did not calculate numbers when percentages were provided due to potential rounding errors.

Authors' note: Address correspondence concerning this article to Nicholas W. Gelbar at gelbar@uchc.edu. 